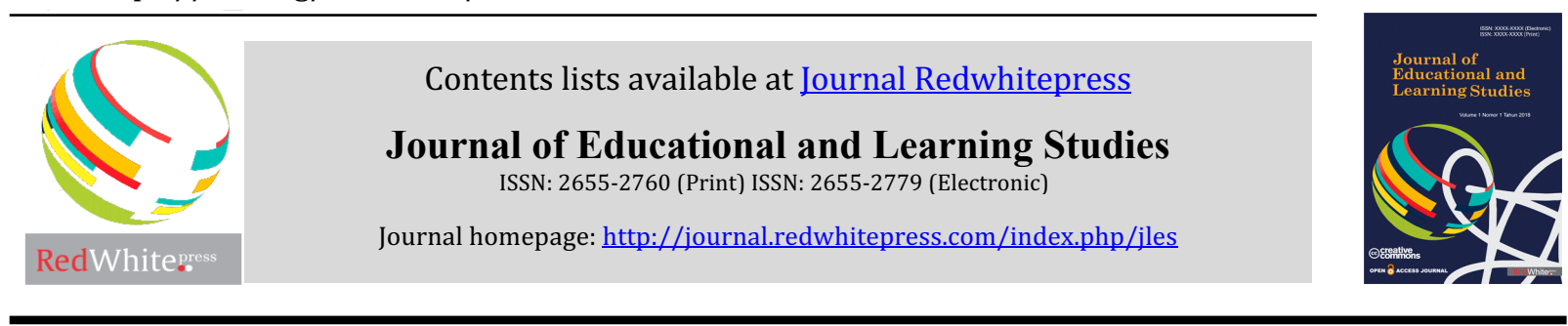

\title{
Identifying Gay Behavior Through Guidance and Counseling Module For Senior High School Students
}

\author{
Gusnaldi $^{1}$, Mudjiran $^{1}$, Afdal $^{1^{*}}$ \\ ${ }^{1}$ Universitas Negeri Padang, Indonesia
}

\begin{tabular}{l}
\hline \hline Article Info \\
\hline Article history: \\
Received Jan $18^{\text {th }}, 2020$ \\
Revised Jun $22^{\text {th }}, 2020$ \\
Accepted Aug $12^{2 \mathrm{t}}, 2020$ \\
\hline
\end{tabular}

\section{Keyword:}

Gay behavior

Counseling module

Senior high school

\begin{abstract}
Homosexuality is defined as romantic attraction, sexual attraction, or sexual behavior between the same sex or gender. Gay is one of the sexual disorders where man is attracted to other straight or gay man. Mostly, teenagers are unaware of this current emerging phenomenon. So, some may get involved or even dragged into this crisis which will lead them to miserable mental state. Their lack of knowledge about the concept and detrimental effect of gay behavior is also the main concern. Hence, a preventive approach should be taken to hinder teenagers, especially male students, from the negative outcome of gay behavior through guidance and counselling program. The paper followed the procedure in descriptive research design. The research population was all public high school students in Padang and there were 100 respondents which was chosen through purposive sampling. Based on the research findings, 15 students $(15 \%)$ responded in the highest scale, extremely concerned. 23 students (23) were moderately concerned. 58 students $(58 \%)$ seemed in uncertainty. 4 students (4\%) were at loss or slightly concerned facing this crisis. In brief, most students had low awareness of this crisis. Thus, their understanding in gay behavior must be enhanced. The aid offered to help them protect themselves is providing information about the concept of gay behavior, gay characteristics, the causes of gay behavior, the impact of being a homosexual man and how they find a sexual partner through guidance and counseling program.
\end{abstract}

(C) 2020 The Authors. Published by Redwhitepress.

This is an open access article under the CC BY-NC-SA license

(https://creativecommons.org/licenses/by-nc-sa/4.0/

\section{Corresponding Author:}

Afdal

Universitas Negeri Padang

Email: afdal@konselor.org

\section{Introduction}

People believe that positive changes in human behavior will prepare their future generation to live in a better and joyful life. However, a rapid technology development does not only bring positive influences. The negative impact can be observed through their new lifestyle, e.g. fulfilling primary and secondary needs while neglecting moral and religious values. There is no binding rule that control them in socializing. Students are involved in free sex, brawl, road raid, even sexual disorder or widely known as LGBT (Lesbian, Gay, Bisexual and Transgender). Sinyo (2014) suggested that LGBT (Lesbian, Gay, Bisexual and Transgender) has distinctive interpretation. First, lesbian is a woman sexual orientation disorder where she desires otherwoman as sex-partner. Similarly, gay is the same-sex gender disorder for men. On the other hand, bisexual is a sexual orientation where a man or a woman likes both genders. Lastly, transgender is a sexual orientation where a man changes his physical and mental appearances into a woman or vice versa. Thus, LGBT is a serious sexual disorder which exists as a contrast belief against Indonesia society, religion and local custom. 
This research is mainly focused on men same-sex sexual orientation, gay. Gay is a common term that related to any homosexuality traits. Noviandy (2012) explained that gay is a man sexual orientation who desire straight or mutual gay man. It is obviously a sexual disorder. The gay community promotes their belief implicitly into society. Students, who have low self-awareness, will find themselves involved in this crisis. It is already known that gay community exists in Padang. Based on the survey conducted by West Sumatera Development Planning Agency in 2017, Padang had the highest registered gay community in West Sumatera and scored as the first rank in the whole nation.

Based on the given survey, a counter-measure movement should be taken to prevent gay behavior. The best solution is by providing students with information, related knowledge, sex-education and the danger of sexual disorder. Wardhani (2013) stated that a teenager, who has proper knowledge of sex education, will be more responsible and engage themselves in positive activity.School also play a vital role in preventing gay behavior on male students. The parents are expected to explain to those teenagers what is sex education, and any related knowledge. Then, school and social community will support them by giving more detailed information needed. Several solution offered are guidance and counseling program and an integrated sex education in school subjects. Sulaeman's (2016) research findings showed that guidance and counseling teacher have prevented sexual disorder (gay) through interpersonal communication. Yet, it failed to obtain satisfying results since it took so much time to consult the whole students and the lack of teachers cooperation. To assist the whole students, a guidance and counseling teacher can conduct a classical service such as: providing information. A classical information service is able to improve students' understanding on teens puberty and preventing gay behavior.

Guidance and counseling services play a role in preventing and overcoming Gay behavior. Hikmawati (2012) stated that schools' guidance and counseling services have preventive measure on students' characters development. In brief, guidance and counseling program is responsible in anticipating students' problem and unwanted behavior. The teacher provides guidance and counseling for the clients/students to divert them from any harmful action. Prayitno (2015) discussed three major reasons why providing the necessary information is essential. First, to provide an individual with various knowledge, so they are able to face and solve their problem. Second, to determine his or her life long-term goal, and to make decision based on their individual personality. Hence, informational service is a vital aid for students in getting new knowledge to aim for potent life.

Guidance and counseling teachers can blatantly conduct a direct information service through various and flexible media or techniques. They may choose to do classical or group service that depend on the type of information and students' characteristics. To optimize the guidance and counseling service, especially in gay behavior, teacher should own an adequate guidebook, module and broad knowledge in related topic. So, the students will acquire sufficient information to protect themselves. According to the phenomena and facts explained above, the writer wanted to develop a guidance and counseling module to assist peer school teachers and help students' in understanding or preventing gay behavior. Students are expected to develop their potentials independently, prevent themselves from any incoming threat, and utilize the module. This approach reflects the goal of guidance and counseling program where assisting and guiding students as the main goals. Prayitno (2009) defined that "counseling service aims for independent, successful individual and potent life style." Thus, the writer was interested to inspect students' perspective on gay behavior.

\section{Method}

Quantitative research with descriptive research design was implemented. Quantitative research emphasizes on number, numerical data, that are processed through statistical method. There are 16 senior high schools in Padang which was included in research population. To have better control of this wide number of populations, a sampling was conducted. The cluster random sampling was conducted based on the school's credibility.

There are 5 stages for the application of cluster sampling: (1) formulate population characteristics, (2) determine the cluster, (3) determine the sample size of each cluster, (4) choose randomly from each cluster, (5) make a list of chosen samples. After following those procedures, several schools were chosen as representative. SMA Negeri 2 Padang and SMA Negeri 9 Padang were the representative of A accreditation. While for B accreditation, SMA Negeri 13 Padang and SMA Negeri 15 Padang was selected. Later, 100 students were drawn as the sample which consisted of 25 students from each selected school. The research population and sample are listed in Table 1 below. 
Table. 1 Research Population and Sample

\begin{tabular}{|c|c|c|c|c|c|}
\hline \multirow[t]{2}{*}{ No } & \multicolumn{2}{|c|}{ Population } & \multicolumn{2}{|c|}{ Sample } & \multirow[t]{2}{*}{ Respondent } \\
\hline & School & Accreditation & School & Accreditation & \\
\hline 1 & SMAN 1 Padang & $\mathrm{A}$ & \multirow[t]{8}{*}{ SMAN 2 Padang } & \multirow[t]{8}{*}{$\mathrm{A}$} & \multirow[t]{8}{*}{25 Students } \\
\hline 2 & SMAN 2 Padang & A & & & \\
\hline 3 & SMAN 3 Padang & A & & & \\
\hline 4 & SMAN 4 Padang & A & & & \\
\hline 5 & SMAN 5 Padang & A & & & \\
\hline 6 & SMAN 6 Padang & A & & & \\
\hline 7 & SMAN 7 Padang & $\mathrm{A}$ & & & \\
\hline 8 & SMAN 8 Padang & $\mathrm{B}$ & & & \\
\hline 9 & SMAN 9 Padang & $\mathrm{A}$ & \multirow[t]{4}{*}{ SMAN 9 Padang } & \multirow[t]{4}{*}{$\mathrm{A}$} & \multirow[t]{4}{*}{25 Students } \\
\hline 10 & SMAN 10 Padang & $\mathrm{A}$ & & & \\
\hline 11 & SMAN 11 Padang & B & & & \\
\hline 12 & SMAN 12 Padang & B & & & \\
\hline 13 & SMAN 13 Padang & $\mathrm{B}$ & \multirow[t]{2}{*}{ SMAN 13 Padang } & \multirow[t]{2}{*}{ B } & \multirow[t]{2}{*}{25 Students } \\
\hline 14 & SMAN 14 Padang & B & & & \\
\hline 15 & SMAN 15 Padang & B & \multirow[t]{2}{*}{ SMAN 15 Padang } & \multirow[t]{2}{*}{ B } & \multirow[t]{2}{*}{25 Students } \\
\hline 16 & SMAN 16 Padang & B & & & \\
\hline & \multicolumn{4}{|c|}{ Total } & 100 students \\
\hline
\end{tabular}

This research used close ended question in its questionnaire and adapted Likert Scale to measure students' level of understanding towardthe concept of gay behavior, characteristics of homosexual men, the causes of gay behavior, the impact of being a gay, and homosexual men preferences for sexual partner. 100 high school students studying in Padang were chosen through purposive sampling. The research used five scale: Extremely concerned, moderately concerned, somewhat concerned, slightly concerned, and not at all concerned.

\section{Results and Discussions}

The research discussion, an analysis of students' understanding toward gay behavior, is presented in this following table.

Table 2. Students' Understanding toward Gay Behaviorat SMAN 15 Padang (n=100)

\begin{tabular}{cccc}
\hline No. & Category & F & $\mathbf{\%}$ \\
\hline $\mathbf{1}$ & Extremely Concerned & 15 & 15 \\
\hline $\mathbf{2}$ & Moderately Concerned & 23 & 23 \\
\hline $\mathbf{3}$ & Somewhat Concerned & 58 & 58 \\
\hline $\mathbf{4}$ & Slightly Concerned & 4 & 4 \\
\hline $\mathbf{5}$ & Not at all Concerned & 0 & 0 \\
\hline
\end{tabular}

The table showed that 15 students were extremely concerned, 58 students were somewhat concerned and no answer detected in not at all concerned scale. It can be concluded that students of SMAN 15 Padang were unconcerned about gay behavior. It meant that they have not fully understand what this disorder was. This ignorance may lead the students getting involved in gay behavior later. To measure the second indicator, the concept of gay behavior, table 3 presented the result.

Table 3. Students' Understanding on the Concept of Gay Behavior.

\begin{tabular}{cccccccc}
\hline No & Statement & \multicolumn{5}{c}{ Likert Scale } & Total \\
\cline { 3 - 7 } & & $\begin{array}{c}\text { Extremely } \\
\text { Concerned }\end{array}$ & $\begin{array}{c}\text { Moderately } \\
\text { Concerned }\end{array}$ & $\begin{array}{c}\text { Somewhat } \\
\text { Concerned }\end{array}$ & $\begin{array}{c}\text { Slightly } \\
\text { Concerned }\end{array}$ & $\begin{array}{c}\text { Not at all } \\
\text { Concerned }\end{array}$ & \\
\hline $\mathbf{1}$ & 1 & 19 & 24 & 55 & 2 & 0 & 100 \\
\hline & Total & 19 & 24 & 55 & 2 & 0 & 100 \\
\hline & Average & & 24 & $\mathbf{5 5}$ & $\mathbf{2}$ & $\mathbf{0}$ & $\mathbf{1 0 0}$ \\
\hline
\end{tabular}


In summary, out of 100 students, 19\% were extremely aware of the gay behavior concept. 24 students answered very aware, $55 \%$ were uncertain and $2 \%$ were slightly aware. It means that almost half of them did not understand the concept of gay behavior.

Table 4. Students' Understanding on the Characteristics of Gay Men

\begin{tabular}{cccccccc}
\hline \multirow{2}{*}{ No } & Statements & \multicolumn{2}{c}{ Likert Scale } & \multicolumn{2}{c}{ Total } \\
\cline { 2 - 6 } & & $\begin{array}{c}\text { Extremely } \\
\text { Concerned }\end{array}$ & $\begin{array}{c}\text { Moderately } \\
\text { Concerned }\end{array}$ & $\begin{array}{c}\text { Somewhat } \\
\text { Concerned }\end{array}$ & $\begin{array}{c}\text { Slightly } \\
\text { Concerned }\end{array}$ & $\begin{array}{c}\text { Not at all } \\
\text { Concerned }\end{array}$ \\
\hline $\mathbf{2}$ & 19 & 24 & 55 & 2 & 0 & 100 \\
\hline 2 & 13 & 28 & 57 & 2 & 0 & 100 \\
\hline 3 & 15 & 25 & 57 & 3 & 0 & 100 \\
\hline 4 & 17 & 26 & 54 & 3 & 0 & 100 \\
\hline 5 & 13 & 29 & 55 & 2 & 0 & 100 \\
\hline 6 & 12 & 25 & 58 & 4 & 0 & 100 \\
\hline 7 & 13 & 27 & 56 & 4 & 0 & 100 \\
\hline 8 & 13 & 25 & 54 & 4 & 0 & 100 \\
\hline 9 & 17 & $\mathbf{2 3 9}$ & $\mathbf{5 0 3}$ & $\mathbf{2 6}$ & $\mathbf{0}$ & $\mathbf{9 0 0}$ \\
\hline 10 & $\mathbf{1 3 2}$ & $\mathbf{2 6 , 5 5}$ & $\mathbf{5 5 , 8 9}$ & $\mathbf{2 , 9}$ & $\mathbf{0}$ & \\
\hline
\end{tabular}

Table 4 presented that 14,66\% was extremely aware of gay characteristics, $26,55 \%$ was very aware, $55,89 \%$ was uncertain and $2,9 \%$ was slightly aware. In short, most students did not understand the characteristics of gay men.

Table 5. Students' Understanding on the Causes of Gay Behavior

\begin{tabular}{|c|c|c|c|c|c|c|c|}
\hline \multirow[t]{2}{*}{ No } & \multirow[t]{2}{*}{ Statements } & \multicolumn{5}{|c|}{ Likert Scale } & \multirow[t]{2}{*}{ Total } \\
\hline & & $\begin{array}{l}\text { Extremely } \\
\text { Concerned }\end{array}$ & $\begin{array}{l}\text { Moderately } \\
\text { Concerned }\end{array}$ & $\begin{array}{l}\text { Somewhat } \\
\text { Concerned }\end{array}$ & $\begin{array}{c}\text { Slightly } \\
\text { Concerned }\end{array}$ & $\begin{array}{l}\text { Not at all } \\
\text { Concerned }\end{array}$ & \\
\hline \multirow[t]{9}{*}{3} & 11 & 10 & 12 & 58 & 16 & 4 & 100 \\
\hline & 12 & 14 & 22 & 59 & 5 & 0 & 100 \\
\hline & 13 & 12 & 21 & 61 & 6 & 0 & 100 \\
\hline & 14 & 13 & 21 & 61 & 5 & 0 & 100 \\
\hline & 15 & 16 & 20 & 61 & 3 & 0 & 100 \\
\hline & 16 & 16 & 23 & 58 & 3 & 0 & 100 \\
\hline & 17 & 17 & 22 & 62 & 3 & 0 & 100 \\
\hline & Total & 98 & 141 & 420 & 41 & $\mathbf{0}$ & 700 \\
\hline & Average & 14 & 20,14 & 60 & 5,86 & $\mathbf{0}$ & 100 \\
\hline
\end{tabular}

Data recorded in table 5 as follows: $14 \%$ is extremely aware of gay behavior, $20.14 \%$ was very aware, $60 \%$ was uncertain, $5.86 \%$ was slightly aware and there was none in unaware choice. It meant that most of the students were lack of information what caused gay behavior.

Table 6. Students' Understanding on the Impact of Gay Behavior

\begin{tabular}{|c|c|c|c|c|c|c|c|}
\hline \multirow[t]{2}{*}{ No } & \multirow[t]{2}{*}{ Statements } & \multicolumn{5}{|c|}{ Likert Scale } & \multirow[t]{2}{*}{ Total } \\
\hline & & $\begin{array}{l}\text { Extremely } \\
\text { Concerned }\end{array}$ & $\begin{array}{l}\text { Moderately } \\
\text { Concerned }\end{array}$ & $\begin{array}{l}\text { Somewhat } \\
\text { Concerned }\end{array}$ & $\begin{array}{c}\text { Slightly } \\
\text { Concerned }\end{array}$ & $\begin{array}{l}\text { Not at all } \\
\text { Concerned }\end{array}$ & \\
\hline \multirow[t]{13}{*}{4} & 18 & 15 & 23 & 59 & 3 & 0 & 100 \\
\hline & 19 & 17 & 23 & 57 & 3 & 0 & 100 \\
\hline & 20 & 16 & 23 & 56 & 5 & 0 & 100 \\
\hline & 21 & 14 & 19 & 64 & 3 & 0 & 100 \\
\hline & 22 & 15 & 20 & 62 & 3 & 0 & 100 \\
\hline & 23 & 11 & 24 & 62 & 3 & 0 & 100 \\
\hline & 24 & 13 & 22 & 60 & 5 & 0 & 100 \\
\hline & 25 & 17 & 22 & 58 & 3 & 0 & 100 \\
\hline & 26 & 16 & 24 & 58 & 2 & 0 & 100 \\
\hline & 27 & 18 & 24 & 56 & 2 & 0 & 100 \\
\hline & 28 & 16 & 24 & 57 & 3 & 0 & 100 \\
\hline & Total & 168 & 248 & 649 & 35 & $\mathbf{0}$ & 1100 \\
\hline & Average & 15,27 & 22,55 & 59 & 3,18 & $\mathbf{0}$ & 100 \\
\hline
\end{tabular}


This is the result on the impact of gay behavior test. $15.27 \%$ was extremely aware, $22.55 \%$ was very aware, 59\%was uncertain, while $3.18 \%$ was slightly aware. In conclusion, these students did not understand the impact of gay behavior.

Table 7. Students' Understanding on Gay Men Preference for Sexual Partner.

\begin{tabular}{|c|c|c|c|c|c|c|c|}
\hline \multirow[t]{2}{*}{ No } & \multirow[t]{2}{*}{ Statements } & \multicolumn{5}{|c|}{ Likert Scale } & \multirow[t]{2}{*}{ Total } \\
\hline & & $\begin{array}{l}\text { Extremely } \\
\text { Concerned }\end{array}$ & $\begin{array}{l}\text { Moderately } \\
\text { Concerned }\end{array}$ & $\begin{array}{l}\text { Somewhat } \\
\text { Concerned }\end{array}$ & $\begin{array}{c}\text { Slightly } \\
\text { Concerned }\end{array}$ & $\begin{array}{c}\text { Not at all } \\
\text { Concerned }\end{array}$ & \\
\hline \multirow[t]{9}{*}{5} & 29 & 9 & 15 & 66 & 10 & 0 & 100 \\
\hline & 30 & 17 & 22 & 59 & 2 & 0 & 100 \\
\hline & 31 & 17 & 22 & 58 & 3 & 0 & 100 \\
\hline & 32 & 14 & 25 & 58 & 3 & 0 & 100 \\
\hline & 33 & 17 & 22 & 58 & 3 & 0 & 100 \\
\hline & 34 & 18 & 23 & 57 & 2 & 0 & 100 \\
\hline & 35 & 17 & 19 & 62 & 2 & 0 & 100 \\
\hline & Total & 109 & 148 & 418 & 25 & 0 & 700 \\
\hline & Average & 15.57 & 21.14 & 59.71 & 3.57 & $\mathbf{0}$ & 100 \\
\hline
\end{tabular}

Table 6 showed discussed about gay men preferences on sexual partner. 15,57\% was extremely aware, $21.14 \%$ was very aware, $59.71 \%$ was uncertain and $3.57 \%$ was slightly aware. In short, they do not understand this topic.Based on the instrument obtained, writer compiled discussion topics for preventing gay behavior on high school students.

Table 8. Choosing Topic for PreventingGay behaviour on Male Students.

\begin{tabular}{|c|c|c|c|c|}
\hline No. & Indicator & Statement & Topic & $\%$ \\
\hline \multirow[t]{2}{*}{1.} & Students' & & & \\
\hline & $\begin{array}{l}\text { Understanding on } \\
\text { The Concept of Gay } \\
\text { Behavior }\end{array}$ & $\begin{array}{l}\text { I know that homosexual man or gay only attracted to } \\
\text { other men. }\end{array}$ & $\begin{array}{l}\text { The origin of } \\
\text { Homosexuality }\end{array}$ & 55 \\
\hline \multirow[t]{9}{*}{2} & \multirow{9}{*}{$\begin{array}{l}\text { Students' } \\
\text { Understanding on the } \\
\text { characteristics of gay } \\
\text { men. }\end{array}$} & Gay men wear earrings & \multirow{9}{*}{$\begin{array}{c}\text { Visible } \\
\text { Characteristics } \\
\text { of Gay Men. }\end{array}$} & 57 \\
\hline & & $\begin{array}{l}\text { Gay men dress in flashy outfits like a world-class } \\
\text { celebrity. }\end{array}$ & & 59 \\
\hline & & Gay men move like a girl. & & 60 \\
\hline & & Gay men attracted to men rather than women & & 57 \\
\hline & & $\begin{array}{l}\text { Gay men's thought and ambition are focused on doing } \\
\text { bad deeds because men are easily found around them. }\end{array}$ & & 57 \\
\hline & & Gay men have no shame. & & 59 \\
\hline & & $\begin{array}{l}\text { Gay men tend to act as a frail figure in front of other } \\
\text { men. }\end{array}$ & & 62 \\
\hline & & Gay men tend to do bad deeds. & & 60 \\
\hline & & Gay men are easily offended and sensitive. & & 58 \\
\hline \multirow[t]{7}{*}{3} & \multirow{7}{*}{$\begin{array}{l}\text { Students' } \\
\text { Understanding on the } \\
\text { causes of gay } \\
\text { behavior. }\end{array}$} & $\begin{array}{l}\text { An incomplete chromosome is believed as the cause of } \\
\text { gay behavior. }\end{array}$ & \multirow{7}{*}{$\begin{array}{l}\text { The Causes of } \\
\text { Gay Behavior. }\end{array}$} & 78 \\
\hline & & Unbalanced hormone causes gay behavior. & & 64 \\
\hline & & Absurd mindset causes gay behavior. & & 67 \\
\hline & & Child Traumatic experience causes gay behavior. & & 66 \\
\hline & & $\begin{array}{l}\text { Free sex activity with the same gender causes gay } \\
\text { behavior }\end{array}$ & & 64 \\
\hline & & Child Sexual disorder problem causes gay behavior. & & 61 \\
\hline & & $\begin{array}{l}\text { Bad parenting during a child growth causes gay } \\
\text { behavior. }\end{array}$ & & 63 \\
\hline \multirow[t]{6}{*}{4.} & \multirow{6}{*}{$\begin{array}{l}\text { Students' } \\
\text { Understanding on the } \\
\text { impact of being a gay } \\
\text { man. }\end{array}$} & Gay behavior causes transmitted or contagious diseases. & \multirow[b]{6}{*}{ The impact of } & 66 \\
\hline & & Gay behavior leads to HIV / AIDS & & 60 \\
\hline & & Gay men are not welcomed in their own family. & & 61 \\
\hline & & Gay men is isolated from society. & & 67 \\
\hline & & Gay behavior is defined as sinful, disgusting act by society. & & 65 \\
\hline & & Gay behavior opposes the local custom, and moral & & 65 \\
\hline
\end{tabular}




\begin{tabular}{|c|c|c|c|c|}
\hline No. & Indicator & Statement & $\begin{array}{c}\text { Topic } \\
\text { gay behavior. }\end{array}$ & $\%$ \\
\hline & & values in society & \multirow{6}{*}{ gay behavior. } & \\
\hline & & Gay behavior will end up in miserable death. & & 65 \\
\hline & & Gay behavior ruins family life. & & 61 \\
\hline & & Gay men were left behind by their friends. & & 60 \\
\hline & & Gav behavior leads to low learning motivation. & & 58 \\
\hline & & Gay behavior affect future career. & & 60 \\
\hline \multirow[t]{7}{*}{5} & \multirow{7}{*}{$\begin{array}{l}\text { Students' } \\
\text { understanding on } \\
\text { Gay Men's } \\
\text { preferences in sexual } \\
\text { partner. }\end{array}$} & Gay men interested in cute men. & \multirow{7}{*}{$\begin{array}{c}\text { Characteristics } \\
\text { on Gay } \\
\text { Couple. }\end{array}$} & 80 \\
\hline & & Gay men prefer men who come from broken family. & & 61 \\
\hline & & $\begin{array}{l}\text { Gay men prefer a man who have low religious } \\
\text { knowledge. }\end{array}$ & & 61 \\
\hline & & Gay men prefer slightly tall man & & 61 \\
\hline & & Gay men love innocent man. & & 61 \\
\hline & & Gay men prefer white-skinned man. & & 59 \\
\hline & & $\begin{array}{l}\text { Gay men prefer a man who have no control over his } \\
\text { family }\end{array}$ & & 64 \\
\hline
\end{tabular}

The topics chosen for discussion in conducting guidance and counseling program were recognizing the concept of homosexuality, the characteristics of gay men, the causes of gay behavior, the impact of gay behavior and gay men's preferences on sexual partner. Gay is a sexual orientation disorder in which men are attracted to straight or gay men. The objective was to let students identify this sexual disorder. So, they will grow up into a true healthy man.

The next topic is gay men characteristics. The goal was to build students' self-awareness in recognizing gay men characteristics in their daily life. Thus, they independently prevent themselves to do so. The third topic was the causes of gay behavior. It discussed internal and external conflict which causes normal man turned into gay man. So, the male students will be able to avoid gay behavior in the future.

The fourth topic was the impact of gay behavior. It suggested that gay behavior influenced gay man's health, family relationship, social relation, and learning motivation. The last topic was about gay men'sreferences in looking for sexual partner. Male students must know these points, so they will be able to avoid any temptation from tricky gay men who try to seduce them.

\section{Conclusions}

Gay is a sexual disorder which goes against the nature of teenager sexual orientation. Hence, they won't develop as they should. One of the major causes is teenagers do not possess adequate knowledge of gay behavior. The research findings showed that 15 students $(15 \%)$ responded in the highest scale, extremely concerned. 23 students (23) were moderately concerned. 58 students $(58 \%)$ were in uncertainty. 4 students $(4 \%)$ were at loss or slightly concerned facing this crisis. In conclusion, most students had low concern of this crisis. Thus, teen must acquire more information about gay behavior.

One of the offered solutions to prevent gay behavior on students is providing information about the concept of gay behavior, gay characteristics, the causes of gay behavior, the impact of being a homosexual man and how gay man find a sexual partner through guidance and counseling program.

\section{References}

Hikmawati, F. (2012). Bimbingan dan Konseling. Jakarta: Raja Grafindo Persada.

Noviandi. (2012). LGBT dalam kontroversi sejarah seksualitasdan relasi kuasa. Jurnal Momentum, Vol. 2 (2), 36-41.

Prayitno. (2009). Dasar-dasar bimbingan dan konseling. Jakarta. Rineka Cipta.

Prayitno.,\& Amti, E. (2013). Dasar-dasar bimbingan dan konseling. Jakarta:Rineka Cipta.

Sinyo. (2014). Anakku bertanya tentang LGBT. Jakarta: PT Elex Media Komputindo.

Sulaeman, (2016). Efektivitas komunikasi internasional guru BK dan siswa dalam mencegah peningkatan perilaku lesbi dan gay di SMK.eJournal Ilmu Komunikasi, 4(2), 265-374.

Wardani, (2013). Pengetahuan sikap dan perilaku remaja tentang seks pranikah. Jurnal Keperawatan Maternitas.1(1), 46-54. 